To Maega | Jurnal Pengabdian Masyarakat

Februari 2021, Vol. 4, No. 1, hal 26-34

$\operatorname{ISSN}(P): 2622-6332 ; \operatorname{ISSN}(E): 2622-6340$

http://www.ojs.unanda.ac.id/index.php/tomaega

\title{
Meningkatkan Pemahamanan Pembuatan Pakan Ikan Pada Anggota Kelompok Nelayan Jenber di Kelurahan Tanjung Merdeka, Kota Makassar
}

\author{
Burhanuddin ${ }^{1}$, Andi Khaeriyah ${ }^{1}$, Akmaluddin ${ }^{1}$, Sitti Arwati ${ }^{2}$, \\ Muhamad Ikbal ${ }^{1}$, Asni Anwar 1,*, Hamsah ${ }^{1}$ \\ ${ }^{1}$ Budidaya Perairan, Fakultas Pertanian Universitas Muhammadiyah Makassar \\ ${ }^{2}$ Agribisnis, Fakultas Pertanian Universitas Muhammadiyah Makassar \\ *CorrespondentEmail: asni@unismuh.ac.id
}

Article History:

Received: 16-8-2020; Received in Revised: 17-9-2020; Accepted: 23-9-2020

DOI: http://dx.doi.org/10.35914/tomaega.v4i1.434

\begin{abstract}
Abstrak
Masyarakat di sekitar muara sungai Jeneberang memanfaatkan aliran sungai sebagai tempat budidaya ikan sistem keramba jaring apung (KJA) dengan membudidayakan ikan air tawar seperti ikan lele (Clarias batrachus), ikan nila (Oreochromis niloticus) dan ikan patin (Pangasius sp). Permintaan ikan lele, nila dan patin sangat tinggi, namun produksi ikan belum mampu memenuhi kebutuhan pasar. Beberapa faktor penyebab rendahnya produksi adalah lambatnya pertumbuhan dan sintasan akibat kurangnya nutrisi ikan budidaya sebagai dampak dari kurang optimalnya penggunaan pakan berkualitas akibat harganya yang relatif mahal. Penggunaan pakan buatan yang berkualitas tinggi dengan memanfaatkan limbah organik rumah tangga sangat membantu untuk menyelesaikan beberapa permasalahan pembudidaya, khususnya pada kelompok pembudidaya ikan "Jenber" di Kota Makassar. Peningkatkan pemahaman kelompok nelayan "Jenber" mengenai pemanfaatan limbah organik rumah tangga menjadi pakan ikan dilaksanakan melalui metode penyuluhan pembuatan pakan ikan dengan tehnik fermentasi. Berdasarkan hasil kegiatan yang dilakukan diketahui bahwa tehnik budidaya ikan air tawar khususnya ikan lele, nila, dan patin dilakukan masyarakat dengan memanfaatkan aliran sungai dengan cara yang sederhana tanpa pemanfaatan teknologi tepat guna. Melalui kegiatan penyuluhan ini, kelompok nelayan menjadi mengetahui tehnik pembuatan pakan dengan bahan dasar limbah organik rumah tangga yang tidak bernilai menjadi pakan ikan yang bernilai tinggi serta ramah lingkungan. Saran yang diberikan untuk kegiatan selanjutnya adalah pendampingan yang intensif agar kelompok nelayan dapat konsisten menerapkan metode budidaya ikan yang ramah lingkungan, murah dan efektif, seperti penggunaan pakan dari limbah limbah organik rumah tangga.
\end{abstract}

Kata Kunci: Pakan, limbah organik,ramah lingkungan, sungai Jeneberang.

\section{Abstract}

The community around the mouth of the Jeneberang river utilizes the river flow as a place for fish cultivation in the floating net cage system (KJA) by cultivating freshwater fish such as catfish (Clarias batrachus), Tilapia (Oreochromis niloticus) and Silver Catfish (Pangasius sp). The demand for catfish, tilapia and Silver Catfish is very high,

(C)To Maega / Jurnal Pengabdian Masyarakat. This is an open access article under the CC BY-SA 4.0 license (https://creativecommons.org/licenses/by-sa/4.0/). 
but the fish production field has not been able to meet market needs. Some of the factors causing the low production are slow growth and survival rate due to lack of nutrition for cultured fish as a result of the less than optimal use of quality feed due to the relatively high price. The use of high-quality artificial feed by utilizing household organic waste is beneficial to solve some problems for farmers, especially in the "Jenber" fish farmer group in Makassar. Increasing the understanding of the "Jenber" fishermen group regarding the use of household organic waste into fish feed is carried out through the extension method for making fish feed using fermentation techniques. Based on the results of the activities carried out, it is known that the community carries out freshwater fish farming techniques, especially Catfish, Tilapia, and Silver Catfish by utilizing river flow merely without the use of appropriate technology. Through this outreach activity, the partner groups learned about the technique of making feed with non-valuable organic household waste as high value and environmentally friendly fish feed. Suggestions given for the next activity are intensive assistance so that fish farming groups can consistently apply fish farming methods that are environmentally friendly, inexpensive and effective, such as the use of feed from household organic waste.

Key Word : Feed, Organic waste, Environmentally friendly, Jeneberang river

\section{Pendahuluan}

Wilayah kota Makassar berada pada koordinat $119^{\circ} \mathrm{BT}$ dan $5,8^{\circ} \mathrm{LS}$ dengan ketinggian yang bervariasi antara 1-25 meter dari permukaan laut. Kota Makassar merupakan daerah pantai yang diapit dua muara sungai yakni sungai Tallo yang bermuara di bagian utara kota dan sungai Jeneberang yang bermuara di selatan kota (Pengadilan Negeri Makassar, 2016).

Sungai Jeneberang berada di wilayah Kelurahan Tanjung Merdeka merupakan muara utara sungai Jeneberang yang telah tertutup dengan adanya tanggul yang dibangun pada tahun 1993 (Dinas PSDA, 2015). Hal tersebut menyebabkan sungai Jeneberang tidak lagi mengalirkan air secara terus menerus ke laut, sehingga sangat potensial dimanfaatkan masyarakat untuk kegiatan budidaya ikan air tawar, penangkapan ikan, dan penambangan pasir. Umumnya masyarakat membudidayakan ikan dengan sistem keramba. Hasil penelitian Baharuddin R dkk 2018, menyatakan bahwa tehnik budidaya ikan yang dominan dilakukan oleh masyarakat sekitar bantaran sungai Jeneberang yaitu sistem keramba jaring apung (KJA).

Pengembangan usaha budidaya ikan air tawar sistem keramba jaring apung disepanjang bantaran sungai Jeneberang masih mengalami beberapa hambatan, diantaranya masalah tingginya harga pakan komersial, penanganan penyakit serta perubahan kualitas air pada saat cuaca ekstrim. Hasil wawancara dengan ketua kelompok Jenber bahwa jumlah produksi pada tahun 2016-2018 rata-rata 20-30 $\mathrm{kg}$ per keramba, dimana ukuran keramba jaring apung (KJA) 6x6 meter dengan kedalaman 1 meter, namun terjadi penurunan pada tahun 2019-2020 dengan jumlah produksi $10-15 \mathrm{~kg}$ perkeramba. Hal ini diduga akibat mahalnya harga pakan komersial serta perubahan kualitas air. Menurut Suri (2017) bahwa pertumbuhan dan tingkat kelangsungan hidup merupakan parameter utama 
keberhasilan budidaya, dan pakan menjadi salah satu faktor penentu terhadap laju pertumbuhan dan tingkat kelangsungan hidup dalam budidaya ikan dan udang.

Kurang optimalnya pertumbuhan ikan pada budidaya sistem keramba Jaring Apung di Sungai Jeneberang akibat minimnya pengetahuan masyarakat dalam tehnik budidaya serta pembuatan pakan yang murah dan berkualitas dengan memanfaatkan limbah organik rumah tangga. Sebagaimana dinyatakan oleh Wulandari dkk (2018) bahwa salah satu faktor penting dalam budidaya ikan adalah ketersediaan pakan yang berkualitas, oleh karena itu pemberian pakan yang berkualitas diharapkan dapat meningkatkan efisiensi pakan dan meningkatnya pertumbuhan ikan.

Secara ekonomis, usaha budidaya ikan sangat menguntungkan karena ikan memiliki nilai ekonomi yang sangat tinggi. Di samping itu, ikan juga sangat mendukung bagi pemenuhan gizi bagi masyarakat (Cahyono, 2000). Selain itu, usaha budidaya ikan air tawar dapat menurunkan angka pengangguran. Berasarkan hal tersebut, keberlanjutan usaha budidaya ikan air tawar dengan sistem keramba jaring apung disepanjang aliran sungai Jeneberang sangat diharapkan oleh masyarakat. Budidaya dengan sistem keramba jaring apung ini sangat diminati warga karena pemeliharaannya tidak menghabiskan waktu banyak, sehingga pembudidaya dapat melakukan aktifitas mencari nafkah yang lain dengan berbagai profesi seperti buruh bangunan, tukang ojek atau karyawan swasta.

Kurangnya informasi yang diperoleh masyarakat mengenai tehnik pembuatan pakan dengan memanfaatkan limbah organik rumah tangga menyebabkan pembudidaya ikan masih sangat tergantung pada pakan buatan, sehingga pembudidaya ikan harus menyiapkan biaya yang banyak agar proses produksi dapat berjalan sesuai rencana dengan harapan hasil produksi dapat diperoleh secara maksimal (Maryani dkk 2019). Padahal dalam usaha budidaya ikan air tawar, pakan merupakan biaya terbesar karena bisa mencapai 75\% dari total biaya yang dibutuhkan. Salah satu kendala yang dihadapi para pembudidaya di lapangan adalah harga pakan yang cukup mahal sehingga tidak terjangkau oleh masyarakat. Mahalnya harga pakan mengakibatkan kurangnya minat masyarakat untuk mengembangkan usahanya karena keuntungan yang didapatkan kurang maksimal bahkan bisa merugi (Yunaidi dkk, 2018).

Pemanfaatan pakan buatan dengan memanfaatkan limbah organik rumah tangga, seperti penggunaan ampas kelapa terfermentasi, serta limbah dari sisa nasi dan sayur menjadi alternatif bahan pakan yang murah dan ramah lingkungan menjadi tujuan dari kegiatan pengabdian ini. Keberlanjutan penyuluhan ini sangat diharapkan oleh pembudidaya sehingga terjadi transfer iptek mengenai tehnik budidaya ikan air tawar antara Perguruan Tinggi khususnya dari Fakultas Pertanian Universitas Muhammadiyah Makassar dengan masyarakat pembudidaya ikan di Sungai Jeneberang. 


\section{Metode}

Kegiatan pengabdian yang dilakukan untuk menyelesaikan masalah tersebut yaitu dengan melakukan penyuluhan kepada masyarakat yang bertujuan untuk meningkatkan pemahaman masyarakat mengenai pembuatan pakan ikan yang murah, berkualitas serta ramah lingkungan. Kegiatan dilaksanakan melalui penyuluhan yang ditujukan kepada masyarakat kelurahan Tanjung Merdeka pada hari Minggu, 19 Juli 2020 di halaman rumah ketua kelompok Jenber Kelurahan Tanjung Merdeka. Langkah-langkah yang ditempuh untuk mencapai tujuan tersebut adalah sebagai berikut:

a. Melakukan diskusi dengan mitra untuk mengetahui permasalahan yang dihadapi oleh mitra. Berdasarkan hasil diskusi tersebut dapat diidentifikasi permasalahan-permasalahan yang dihadapi oleh mitra. Selanjutnya tim pelaksana dan mitra sepakat memilih permasalahan yang akan diselesaikan melalui kegiatan tim pelaksanaan kepada masyarakat dan merumuskan solusi terpilih. Kegiatan ini dilakukan sebelum penyusunan proposal.

b. Melakukan koordinasi dengan ketua kelompok pembudidaya ikan air tawar untuk menentukan waktu dan areal pelaksanaan kegiatan.

c. Melaksanakan penyuluhan tentang penggunaan limbah organik rumah tangga untuk pembuatan pakan ikan. Kegiatan ini dilakukan kepada anggota Kelompok nelayan "Jenber" yang bertempat di Kelurahan Tanjung Merdeka Kota Makassar. Materi penyuluhan yang diberikan meliputi materi tehnik budidaya ikan air tawar serta tehnik pembuatan pakan ikan melalui pemanfaatan limbah organik rumah tangga yaitu limbah yang dapat mengalami penguraian seperti limbah sayur, ampas kelapa dan sisa nasi melalui sistem fermentasi anaerob (tanpa udara) dengan tujuan agar kandungan limbah tersebut dapat termanfaatkan secara optimal.

d. Metode pembuatan pakan dari ampas kelapa terfermentasi yaitu ampas kelapa yang telah dikukus dan dikeringkan sebanyak $25 \mathrm{~kg}$, ditambah ragi sebanyak 6 butir dan dicampur mineral B12 0,5 kg selanjutnya dimasukkan kedalam drum plastik disimpan secara anaerob selama 2-3 hari kemudian dikeringkan.

e. Melakukan pendampingan. Kegiatan ini dilaksanakan untuk menjamin keberlangsungan program dan memastikan mitra dapat melaksanakan kegiatan seperti yang telah direncanakan.

\section{Hasil dan Pembahasan}

Sebelum Kegiatan pelaksanaan ini diawali dengan tahapan survei dan koordinasi dengan mitra yang dilakukan pada awal bulan Maret 2020, dalam hal ini tim pelaksana melakukan koordinasi bersama Kelompok Jenber, Kelurahan Tanjung Merdeka Kota Makassar. Berdasarkan hasil koordinasi, tim pelaksana akan memberikan penyuluhan mengenai sistem budidaya dan tehnik pembuatan 
pakan yang murah dan ramah lingkungan kepada anggota kelompok budidaya ikan lele dan ikan nila pada sistem keramba jaring apung.

Penyuluhan dilaksanakan pada bulan Juli 2020, yang dihadiri oleh seluruh anggota kelompok nelayan Jenber berjumlah sepuluh orang dengan materi mengenai cara pembuatan pakan ikan air tawar khususnya ikan lele, ikan nila dan ikan patin dengan memanfaatkan beberapa limbah organik rumah tangga misalnya pemanfaatan limbah ampas kelapa, nasi sisa dan beberapa limbah sayur lainnya. Materi penyuluhan dibawakan oleh Dr.Ir.Andi Khaeriyah M.Pd, sedangkan materi tehnik budidaya ikan air tawar dibawakan oleh Dr.Burhanuddin S.Pi.,M.Si. Penyuluhan dilaksanakaan pada masa pandemi Covid-19 sehingga jumlah peserta dibatasi dan memakai masker. Peserta sangat antusias mengikuti jalannya penyuluhan, menurut hasil diskusi dengan para peserta, bahwa penyuluhan ini sangat bermanfaat untuk keberlanjutan usaha budidaya pada keramba jaring apung, dengan ilmu yang didapatkan dalam penyuluhan, kelompok nelayan dapat memanfaatkan limbah rumah tangga yang tidak bernilai menjadi pakan yang bernilai tinggi untuk pakan ikan air tawar, sehingga meminimalkan harga pembelian pakan komersial.

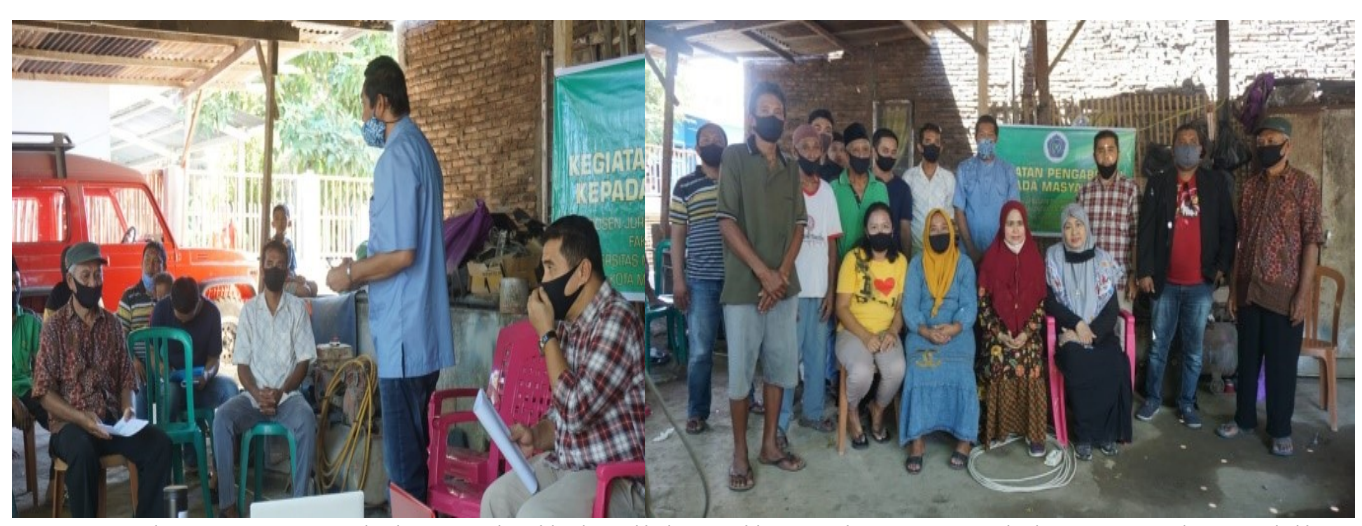

Gambar 1. Penyuluhan tehnik budidaya ikan air tawar oleh Dr.Burhanuddin S.Pi.MP serta berfoto bersama peserta pelatihan dari anggota kelompok nelayan Jenber.

Usaha budidaya ikan lele dan ikan nila di sungai Jeneberang melalui sistem keramba jaring apung sangat membantu kelompok usaha untuk meningkatkan perekonomian keluarga, namun masih terkendala mahalnya harga pakan serta minimnya pengetahuan mengenai tehnik budidaya. 


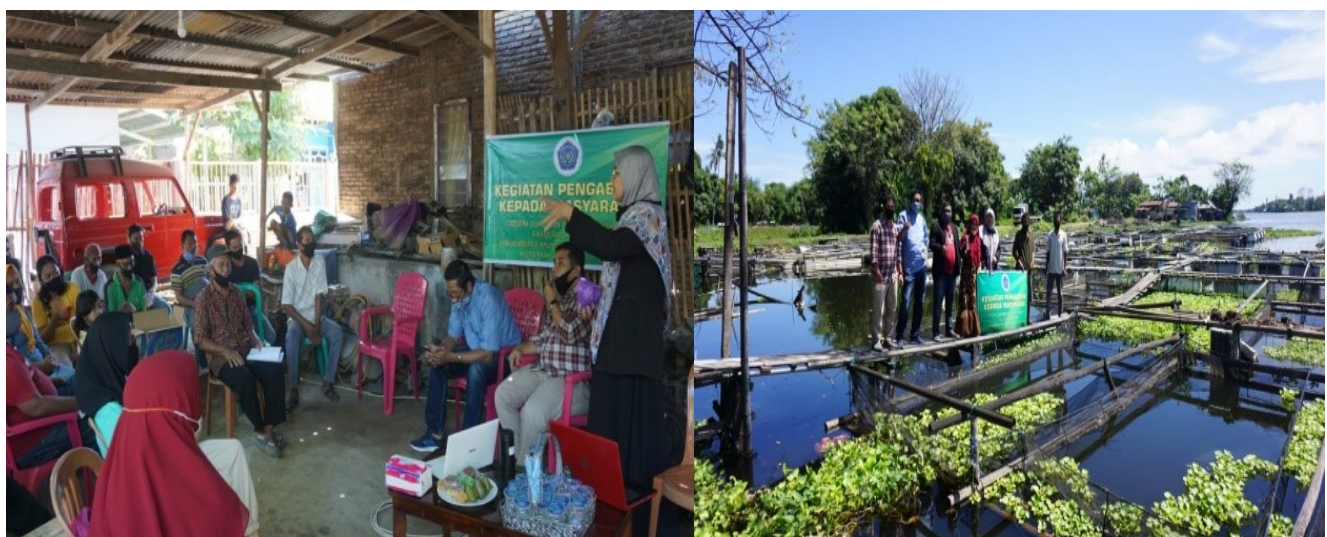

Gambar 2. Penyuluhan Pembuatan Pakan ikan Oleh Dr.Ir.Andi Khaeriyah M.Pd dan pemantauan kondisi budidaya pada Keramba Jaring Apung milik kelompok nelayan Jenber.

Prospek usaha budidaya ini sangat menjanjikan, menurut kelompok mitra, permintaan ikan lele konsumsi sangat tinggi, untuk rumah makan dalam kota Makassar dan lintas daerah misalnya ke Kabupaten Tana Toraja, namun permintaan masih belum terpenuhi akibat kurang optimalnya budidaya, hal ini disebabkan oleh beberapa hal misalnya tingginya biaya produksi akibat mahalnya harga pakan komersial, minimnya pengetahuan dalam penanganan penyakit ikan. Untuk ikan nila, lele dan patin waktu pemeliharaan mulai dari penebaran bibit sampai panen sekitar 3-4 bulan sehingga dalam satu tahunnya panen dapat dilakukan sebanyak 3 kali sedangkan untuk ikan hias (koi) itu bisa dipanen setelah umur 2 - 3 bulan. Harga jual untuk ikan lele sekitar 10.000 sampai 12.000 per kilogram, ikan nila 25.000/kg sedangkan ikan koi biasanya dijual per ekor dengan harga 2.000 sampai 3.000 per ekornya. Walaupun usaha budidaya ikan air tawar berlangsung sepanjang tahun namun hasil panen yang didapatkan tidak sama dalam setiap bulannya. Menurut informasi dari masyarakat hasil panen maksimal bisa didapatkan selama 6 bulan yaitu pada bulan April sampai bulan Agustus sedangkan pada bulan September sampai Maret hasil panen berkurang karena tingkat kematian ikan yang tinggi. Secara ekonomis, usaha budidaya ikan sangat menguntungkan karena ikan memiliki nilai ekonomi yang sangat tinggi. Di samping itu, ikan juga sangat mendukung bagi pemenuhan gizi bagi masyarakat (Cahyono, 2000).

Hasil dilapangan, ditemukan masyarakat masih belum mengetahui cara pembuatan pakan dengan memanfaatkan limbah limbah rumah tangga, sehingga sangat dibutuhkan pemahaman dan peningkatan keterampilan pembuatan pakan ikan air tawar. Berdasarkan hasil diskusi, pemanfaatan sungai Jeneberang sebagai lahan budidaya ikan dengan sistem Keramba Jaring Apung telah membuka lapangan pekerjaan bagi masyarakat, khususnya masyarakat sekitar bantaran sungai dan telah mengurangi jumlah pengangguran. Budidaya ikan dengan Sistem KJA ini penting bagi masyarakat sebagai lahan mencari nafkah/menjadi 
mata pencaharian alternatif (MPA) untuk menambah penghasilan ekonomi keluarga.

Selain memberikan informasi mengenai materi penyuluhan tentang tehnik budidaya ikan air tawar dan pembuatan pakan ikan. Tim pelaksana juga mendapatkan feedback dari peserta penyuluhan berupa angket yang berisi beberapa pernyataan sebelum dan setelah penyuluhan dilakukan.

Tabel 1. Data perbandingan rata-rata nilai setiap pernyataan angket sebelum dan sesudah penyuluhan.

\begin{tabular}{llcc}
\hline No & \multicolumn{1}{c}{ Pernyataan } & $\begin{array}{c}\text { Sebelum } \\
\text { Penyuluhan }\end{array}$ & $\begin{array}{c}\text { Setelah } \\
\text { Penyuluhan }\end{array}$ \\
\hline 1 & $\begin{array}{l}\text { Pengetahuan tehnik budidaya ikan } \\
\text { air tawar }\end{array}$ & 2,50 & 3.00 \\
\hline 2 & $\begin{array}{l}\text { Pengetahuan jenis jenis penyakit } \\
\text { ikan air tawar }\end{array}$ & 2 & 2,85 \\
\hline 3 & $\begin{array}{l}\text { Pengetahuan pengendalian penyakit } \\
\text { pada ikan air tawar }\end{array}$ & 2 & 3.00 \\
\hline 4 & $\begin{array}{l}\text { Pemanfaatan limbah organik rumah } \\
\text { tangga untuk menjadi pakan ikan } \\
\text { melalui tehnik fermentasi }\end{array}$ & 1 & 3.00 \\
\hline 5 & $\begin{array}{l}\text { Pengetahuan budidaya ikan ramah } \\
\text { lingkungan }\end{array}$ & 2 & \\
\hline
\end{tabular}

Angket yang diberikan kepada pembudidaya ikan ini diberikan sebelum dan setelah penyuluhan berlangsung, skala nilai dimulai dari skala 1 dengan kategori belum mengetahui, skala 2 dengan kategori cukup mengetahui dan skala 3 dengan kategori sudah mengetahui.

Berdasarkan hasil angket, rata rata pengetahuan sebelum dilaksanakan penyuluhan berada pada skala 2, namun setelah dilaksanakan penyuluhan pengetahuan kelompok pembudidaya menjadi meningkat, khususnya untuk poin 4 dari kategori belum mengetahui menjadi sudah mengetahui.

\section{Kesimpulan}

Berdasarkan hasil kegiatan pengabdian kepada masyarakat yang dilakukan pada kelompok Jenber yaitu kelompok pembudidaya ikan air tawar di Sungai Jeneberang Kelurahan Tanjung Merdeka dengan sistem Keramba Jaring Apung dapat disimpulkan bahwa tehnik budidaya ikan air tawar khususnya ikan lele, nila, dan patin dilakukan masyarakat dengan memanfaatkan aliran sungai dengan cara yang sederhana tanpa pemanfaatan teknologi tepat guna. Melalui kegiatan penyuluhan ini, kelompok mitra menjadi mengetahui tehnik pembuatan pakan dengan bahan dasar limbah organik rumah tangga yang tidak bernilai menjadi pakan ikan yang bernilai tinggi serta ramah lingkungan. 
Saran yang diberikan untuk kegiatan selanjutnya adalah pendampingan yang intensif agar kelompok nelayan dapat konsisten menerapkan metode budidaya ikan yang ramah lingkungan, murah dan efektif, seperti penggunaan pakan dari limbah limbah organik rumah tangga.

\section{Ucapan Terimakasih}

Pada kesempatan ini kami mengucapkan terima kasih kepada semua pihak yang telah membantu Tim pengabdi PKM selama kegiatan Ipteks berlangsung, secara khusus ucapan terimakasih disampaikan kepada: LP3M Universitas Muhammadiyah Makassar yang telah memberikan kesempatan kepada kami dengan mendanai kegiatan PKM tahun anggaran 2020.

\section{Daftar Pustaka}

Abbas, S.D. (2002). Budidaya Nila Gift Secara Intensif. Yogyakarta: Penerbit Kansisius.

Affan, J. M. (2012). Identifikasi Lokasi Untuk Pengembangan Budidaya Keramba Jaring Apung (KJA) Berdasarkan Faktor Lingkungan dan Kualitas Air di Perairan Pantai Timur Bangka Tengah. Jurnal Depik 1(1).

Baharuddin, R. Hamka, L. Kurnia, N. dan Junda, M. (2017). Kajian Awal Pemanfaatan Sungai Jeneberang Sebagai Sarana Budidaya Ikan Dengan Sistem Keramba. Proceedings of National Seminar. Universitas Negeri Makassar.

Cahyono, B. (2000). Budidaya Ikan Air Tawar. Yogyakarta: Kanisius.

Pengadilan Negeri Makassar. (2016). Diskripsi Wilayah Yuridiksi Kota Makassar. Diakses pada tanggal 12 Juni 2020. http://www.pnmakassar.go.id/website/index.php/tentang-kami/profil-pengadilan-negerimakassar/wilayah-hukum

Pontoh, O. (2014). Analisis usaha perkembangan budidaya ikan dalam jaring apung di Desa Tandengan Kabupaten Minahasa. Jurnal Budidaya Perairan 2(1).

Khairuman, (2002). Budidaya Patin Secara Intensif. Jakarta : PT. Agro Media Pustaka.

Maryani, R.I. dan Nusiah. (2019) .Peningkatan Keterampilan Pembudidaya Ikan Melalui Pelatihan Pembuatan Pakan Herbal Untuk Kelompok Pembudidaya Ikan di Kelurahan Pahandut Seberang, Palangkaraya. Jurnal Pengabdian Pada Masyarakat, 4(2).

Siagian, M. (2010). Strategi Pengembangan Keramba Jaring Apung Berkelanjutan di Waduk PLTA Koto Panjang Kampar Riau. Jurnal Perikanan dan Kelautan 15(2).

Tambunan, F. (2010). Daya Dukung Perairan Danau Lido Berkaitan dengan Pemanfaatannya Untuk Kegiatan Budidaya Perikanan Sistem Keramba Jaring Apung. Institut Pertanian Bogor. 
[ 34 ] Burhanuddin, dkk / To Maega : Jurnal Pengabdian Masyarakat, Vol.4; No.1; Februari 2021

Wulandari, Y. \& Limin, S. (2018). Kajian Pemanfaatan Tepung Ampas Kelapa Sebagai Campuran Pakan Untuk Ikan Lele Dumbo, Clarias Gariepinus (Burchell, 1822). e-Jurnal Rekayasa dan Teknologi Budidaya Perairan, $\mathrm{VI}(2)$

Yunaidi, Rahmanta P.A, \& Wibowo, A. (2019). Aplikasi Pakan Pelet Buatan Untuk Peningkatan Produktivitas Budidaya Ikan Air Tawar di Desa Jerukagung Srumbung Magelang. Jurnal Pemberdayaan: Publikasi Hasil Pengabdian kepada Masyarakat, 3(1). 